CORRIGENDUM

\title{
Mutation of Escherichia coli cytosine deaminase significantly enhances molecular chemotherapy of human glioma
}

SA Kaliberov, JM Markert, GY Gillespie, V Krendelchtchikova, D Della Manna, JC Sellers, LN Kaliberova, ME Black and DJ Buchsbaum

Gene Therapy (2008) 15, 327; doi:10.1038/sj.gt.3303023

Correction to: Gene Therapy (2008) 14, 1111-1119; The correct name is shown above.

doi:10.1038/sj.gt.3302965

The authors would like to apologize for this error.

Since the above publication, the authors have noticed that JM Markert's name was published incorrectly. 